\title{
A Case Study on Plaque Psoriasis with Ayurvedic Management
}

\author{
Case Report
}

\section{Pooja P Thakre1 ${ }^{*}$, Sourabh Deshmukh², Vinod Ade ${ }^{3}$}

1. PG Scholar, 2. Associate Professor, 3. Professor, Department of Kayachikitsa, Mahatma Gandhi Ayurveda College, Hospital and Research Center, Salod (H) Wardha. India

\begin{abstract}
Skin disease is one among Deerghkalinvyadhi (Chronic disease) and also one of the AsthaMahagada (Eight dreadful diseases). The disease psoriasis comes under the Kustha roga. Psoriasis is one of the most common dermatologic disorder and a chronic skin disorder of present day. Almost all the skin disease is explained under Kushta-Rogadhikara (skin disease) and classified as MahaKushta and Kshudra Kushta (Major and Minor skin disease). Acharya have described that all Kushta's have Tri Dosha (three energies) involvement but the type of Kushta depends on the predominance of particular Doshas. The signs and symptoms of Eka-Kushta (psoriasis) in Ayurveda are similar to that of psoriasis explained in modern medicines. Psoriasis is marked by periodic flare-ups of sharply defined red patches, covered by a silvery, flaky surface. Aswedana (Absence of perspiration), Mahavastu (Present all over body), MastyaShakalopama (Look like a fish scale) is the feature mentioned by Acharyas for Ekakushta. In Psoriasis relapsing nature is most common, which suggests that it needs long term treatment. In modern there is no such treatment for psoriasis. Here is the case of $52 \mathrm{yrs}$ old male patient diagnosed as Plaque psoriasis undergone treatment of Shodhan (Purification) i.e. Vaman (Emesis) as well as Shaman Chikitsa (Palitative treatment) having marked improvement. The study showed that combination of Ayurvedic modalities gives significant result in lakshnas (Symptoms) like Aswedana, Mahavastu, MastyaShakalopama.
\end{abstract}

Key Words: Psoriasis, Shodhan, Shaman, Eka-Kushtha.

\section{Introduction}

Psoriasis is common, chronic, recurrent, inflammatory disease of the skin characterized by rounded, circumscribed, erythematous, dry scaling patches of various sizes, covered by grayish white or silvery white lamellar scales. Psoriasis is multi-factorial disease. Triggering factors are infection, drug, trauma etc. About $3 \%$ of world population suffers from psoriasis. In India prevalence of psoriasis varies from $0.44-2.88 \%$ (1). Here is no satisfactory treatment available for Psoriasis. Plaque psoriasis is a type of psoriasis that presents as silvery scaly lesions, well defined erythematous papules or dry, brittle, silvery or grayish white plaque (2). In Ayurveda all types of skin diseases are included under the Kushtha. Acharya Charak mentioned it in Ashtamahagad (3) .Acharya Charak described Kushtha rogadhikar in which he classified Kushtha in to two major types; MahaKushtha and Kshudra Kushtha (4). Amongst various types of Kustha, Eka-kustha is one of them which having a symptoms like Aswedanam (Absence of perspiration),Mahavadstu, Matsyashakalopam (Look

\section{* Corresponding Author:}

\section{Pooja P Thakre}

PG Scholar, Department of Kayachikitsa, Mahatma Gandhi Ayurveda College, Hospital and

Research Center, Salod (H) Wardha. India

Email Id: thakrepooja72@,gmail.com like fish scale) (5) .In samhitas, according to the Bala (Strength), Dosha and Vyadhi avastha (Disease condition), Shodhan and Shaman Chikitsa is described for the Kushtha. Repeated Shodhan is indicated in Kushtha due to Bahu Dosha condition, to eliminated the aggrevated Doshas which helps to treat the root cause of disease. So here a case of Plaque psoriasis (EkaKushtha) is treated successfully with Shodhan (Vaman) and Shaman Chikitsa.

\section{Case report}

A 52 years male patient came with chief complaint of reddish erythematous plaque over both lower limbs with Itching and dryness over them since 2 and half years.

\section{Present History}

Patient was well before two and half years. But since then patient has been suffering from reddish erythematous plaque over both lower limbs with itching and dryness over them. The patient took allopathy medications for above complaints, but there was no any satisfactory relief, so he came to $\mathrm{MGACH} \& \mathrm{RC}$ for further treatment.

\section{Past history}

No any family history was present regarding psoriasis or any dermatological disorders. Disturbed sleep due to the itching. No any history of major illness such as hypertension, diabetes and bronchial asthma. No any history of surgery. 


\section{Personal history} foods.

Frequently consumption of junk, oily and spicy

Ashtavidha Pariksha (Eight folds of examination) was within normal limit but only Sparsha (Touch) was Kharasparsha (Rough to touch) with Rukshta (Dryness). On Examination, all vitals of the patient were within normal limit. Pulse rate was 76 per min regular and VataPittaj, Blood pressure was $110 / 80 \mathrm{~mm}$ of $\mathrm{Hg}$. Respiratory rate was 18 per min, temperature was $98^{\circ} \mathrm{f}$.

\section{Examination of Skin}

A.Inspection

- Lesion- Reddish erythematous graze over both lower limbs

- Color - Red

A.Palpation

- Moisture- Dryness

- Temperature - Warmth to touch

- $\quad$ Texture - Rough

\section{Treatment Plan}

Table no.1:- Shodhan chikitsa - by following the purvakarma, pradhankarma and pschyat karma.

\begin{tabular}{|c|c|c|c|c|}
\hline Date & Medicine & Dose & Route & Duration \\
\hline $\begin{array}{l}12 \text { Nov } 2019- \\
14 \text { Nov } 2019\end{array}$ & $\begin{array}{c}\text { Deepan (Appetizers) } \\
\text {-pachan } \\
\text { (Carminatives) with } \\
\text { Amapachak vati }\end{array}$ & $\begin{array}{c}250 \mathrm{mg} \text { Twice a day } \\
\text { before } \\
\text { meal with lukewarm } \\
\text { water }\end{array}$ & Oral & 3 days \\
\hline $\begin{array}{l}15 \text { Nov 2019- } \\
21 \text { Nov } 2019\end{array}$ & $\begin{array}{c}\text { Abhyantar } \\
\text { Snehapana (Internal } \\
\text { administration) with } \\
\text { Mahatikta grita }\end{array}$ & $\begin{array}{c}30 \mathrm{ml}-1^{\text {st }} \text { day } \\
60 \mathrm{ml}-2^{\text {nd }} \text { day } \\
90 \mathrm{ml}-3^{\text {rd }} \text { day } \\
120 \mathrm{ml}-4^{\text {th }} \text { day } \\
140 \mathrm{ml}-5^{\text {th }} \text { day } \\
160 \mathrm{ml}-6^{\text {th }} \text { day } \\
180 \mathrm{ml}-7^{\text {th }} \text { day } \\
\text { (Empty stomach at } \\
\text { morning } \\
\text { time with lukewarm } \\
\text { water) }\end{array}$ & Oral & 7 days \\
\hline $\begin{array}{l}22 \text { Nov } 2019- \\
23 \text { Nov } 2019\end{array}$ & $\begin{array}{l}\text { Sarvanga abhyanga } \\
\text { followed by nadi } \\
\text { swedan (6) }\end{array}$ & $\begin{array}{l}\text { Marichyadi tail } \\
\text { Followed by } \\
\text { Bashpaswed }\end{array}$ & External application & $\begin{array}{c}\text { For } 2 \text { days } \\
\text { (After completion of } \\
7 \text { days of snehapan) }\end{array}$ \\
\hline $\begin{array}{l}\text { 23rd Nov } 2019 \\
23 \text { Nov 2019- } \\
27 \text { Nov } 2019 \text { (5 } \\
\text { days) }\end{array}$ & $\begin{array}{c}\text { Vamana } \\
\text { (Followed by } \\
\text { sansarjan karma for } \\
5 \text { days) }\end{array}$ & Madanphalyoga & Oral & $\begin{array}{c}\text { For } 1 \text { day at } \\
\text { morning time after } \\
\text { snehan and swedan }\end{array}$ \\
\hline
\end{tabular}

Paschyat Karma - After getting Samyaka Vamana Lakshana, Dhoomapan was given with stick made of Aguru (which is made from Agaru paste apply over cotton and make a stick of it, dried it) for 5 minutes by each nostril. Then patient was advised to follow the Sansarjana Karma for five days. Sansarjana Karma (7) was given in the form of Peya, Vilepi, Akrita Mudga Yusha, Krita Mudga Yusha for 5 days.

Table no.2 Shaman Aushadhi (Pallitative Medication)

\begin{tabular}{|c|c|c|c|c|}
\hline Medicine & Dose & Anupan & $\begin{array}{c}\text { Route of } \\
\text { administration }\end{array}$ & Duration \\
\hline Gandhak Rasayan & $\begin{array}{l}\text { 250mg Twice a day } \\
\text { after meal }\end{array}$ & Luke warm water & Oral & $\begin{array}{l}\text { In interval of } \\
2 \text { months }\end{array}$ \\
\hline Mahatikta grita & $\begin{array}{c}5 \mathrm{ml} \text { (1 Tsf) Twice a } \\
\text { day }\end{array}$ & Luke warm water & Oral & 2 \\
\hline Atrisor cream & $\begin{array}{l}\text { Quantity Sufficient } \\
\text { After bath }\end{array}$ & - & $\begin{array}{l}\text { External } \\
\text { application }\end{array}$ & 2 \\
\hline Vetapallai lubricant & $\begin{array}{c}\text { Quantity Sufficient } \\
\text { At Night }\end{array}$ & - & $\begin{array}{l}\text { External } \\
\text { application }\end{array}$ & 2 month \\
\hline
\end{tabular}




\section{Grading - PASI (Psoriasis Area Severity Index) Score: -}

Within each area, the severity is estimated by three clinical sings: Severity parameters are measured on the scale of 0 to 4, from none to maximum. The body is divided into four sections [head (H) (10\% of a person's skin); arms (A) (20\%): trunk (T) (30\%); legs (L) (40\%)]. Each of this area is scored by itself, and then the four scores are combined into the final PASI. For each section, the percent of area of skin involved, is estimated and then transformed into a grade from 0 to 6 .

Table 3. Showing area involvement with gradation

\begin{tabular}{|c|c|}
\hline No involved area & Grade: 0 \\
\hline$<10 \%$ of involved area & Grade: 1 \\
\hline $10-29 \%$ of involved area & Grade: 2 \\
\hline $30-49 \%$ of involved area & Grade: 3 \\
\hline $50-69 \%$ of involved area & Grade: 4 \\
\hline $90-89 \%$ of involved area & Grade: 5 \\
\hline
\end{tabular}

Table no. 4 Showing assessment criteria of 2 months of treatment Legs

\begin{tabular}{|c|c|c|c|}
\hline & \multicolumn{2}{|c|}{ Legs } \\
\hline & $\begin{array}{c}\text { Before } \\
\text { treatment }\end{array}$ & First follow up & Second follow up \\
\hline Skin area involved Grade - A & 3 & 3 & 0 \\
\hline Erythema (Redness) & 3 & 2 & 0 \\
\hline In duration (Thickness) & 3 & 2 & 0 \\
\hline Desquamation (scaling) E, I, D- B & 4 & 2 & 0 \\
\hline Total PASI Score & 13 & 9 & 0 \\
\hline
\end{tabular}

Table no. 5 Showing Overall result of treatment

\begin{tabular}{|c|c|c|c|}
\hline & Before treatment & First follow up & Second follow up \\
\hline Area involved & $30-49 \%$ & $10-29 \%$ & $0 \%$ \\
\hline Erythema (Redness) & Severe & Mild & Absent \\
\hline In-duration (Thickness) & Moderate & Mild & Absent \\
\hline Desquamation (Scaling) & Severe & Mild & Absent \\
\hline
\end{tabular}

\section{Observation}

Picture no. 1: Showing before treatment and after treatment.

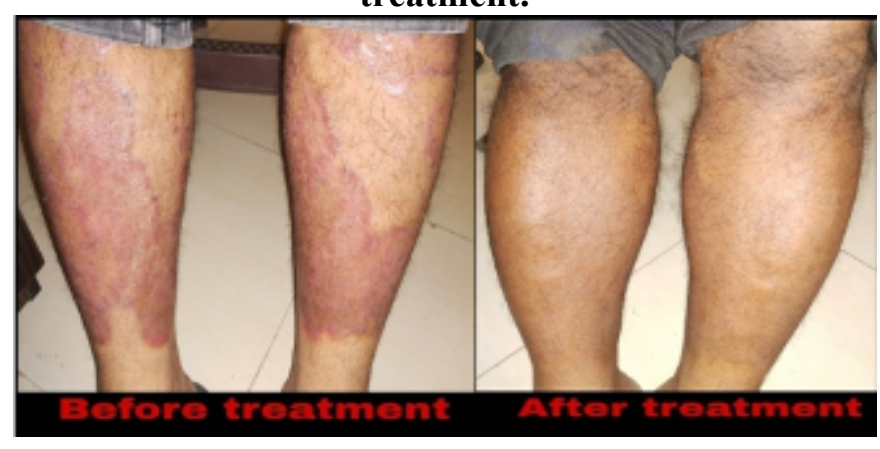

\section{Discussion}

It is the Vyadhi (Disease) of Raktapradoshaj (Disease due to vitiated Rakta), Vata-Kapha Pradhan and Tri-doshaj. The Shodhan and Shaman Chikitsa are described in Samhitas for the management of Kushtha (8). Amongst the Shodhan,Vaman is the best Chikitsa for the Kushtha as it eliminates the Kapha and Pitta sequentially from the body. In the present study Shodhan and Shaman Chikitsa was given to the patient. In Purva Karma, Deepan - Pachana Dravya (Tab. Aamapachak) was given which is Agnivardhak
(Stimulates digestion) and Amapachak. After that Snehapana (Internal oleation) was given with Mahatikta Ghrita for 7 days, it causes the Vatadosha pacification. For the Abhyanga the Marichadi tail was used reduces the dryness, provides the moisturization to the body, improves the blood circulation \& reduces itching. Followed by Sarwanga swedan it does the Dosha-vilayana (liquefies the Doshas) and brings them from Shakhas (Tissue) to Koshta (Visceral organ) to eliminate them. It also removes the Strotas Avarodha (Obstruction in channels).

\section{Action of Snehapana - Mahatikta ghrit}

The ingredients of Mahatikta ghrita are Tikta Rasatmaka, Madhur Vipaki and Ushna Viryatmaka. It acts mainly on Kled, Meda,Lasika, Rakta, Pitta and Kapha which helps in balancing the vitiated Dosha and Dhatu. It has properties like, Raktashodhak (Blood purifier) ,Kushtaghna( Cure skin disease), Kandugha (Pacifying itching) and Varnya (Complexion) (9) . Ghrit (Ghee) has lipophilic action helps to carry drugs to the target organs, it enters to its cellular level and delivers to mitochondria and nuclear membrane. It maintains the normal texture of skin(10) . 


\section{Action of Abhyanga with Marichyadi tail}

For the purpose of Abhyanga or Bahyasnehana (External oleation) the Marichyadi tail is used.

The most of Dravyas of Marichyadi tail are have properties like Katu, Tikta, Kashay rasa and Ushna virya which does the Shaman of Kapha and Vata dosha. Its Snighdha Guna reduces the Rukshatva, Kharatva and Parushata. It has properties like Raktashodhan, Kushtaghna and Kandughna. The nature of tail is Sukshmagamitva means it helps drugs to go into the minute channels and does the proper absorption. The Kashay rasa of these Dravyas helps to reduce the Kleda (11). Marichyadi tail has antiseptic, antifungal, anti-inflammatory, antimmuno modulatory property. The Marichyadi tail is effective in the Symptoms of Eka Kushtha due to these properties.

\section{Action of Vaman karma}

Vaman does the elimination of the Prakupit doshas (Vitiated dosha) mainly Kapha and Pitta from the Koshtha. The Vamanopaga drugs (Aiding in emesis), such as Madanphal Churna, Vacha Churna, Pippali Churna, Saindhav, Madhu, Yashtimadhu Phanta having properties like Ushna, Tikshna, Vyavayi and Vikasi it enhances the absorption rate and helps to reach at Hriday (Heart). It moves from Hriday to the Dhamani (Artery) to all Shukshma and Sthool Strotas. It removes all the toxins from the body. There is Agni and Vayu Mahabhutas prevalence. Urdhwabhagahar Prabhav of Vamak Dravyas which causes the elimination of Doshas from the upward route. This therapy is very effective for the elimination of aggravated Doshas. (12)

\section{Gandhak Rasayan}

It acts as Kushtaghna, Kandughna, Dahaprashaman, Raktashodhak, Vranaropak, Twachya and Krumighna. It is mainly indicated in Kushtaroga. It possess the property like antibacterial, antiviral and antimicrobial (13). It reduces the itching and infection.

\section{Atrisor ointment}

It contains Leptadenia reticulate (Retz.), Rubia cordifolia (Linn.), Curcuma longa (Linn.), Wrightia tinctoria (Roxb.) , Cocos nucifera (Linn.) and Hydrocarpus laurifolia. It is anti-psoriatic properties having complete relief from inflammation, itching and irritation associated with psoriatic lesion. Its action brings back normal skin texture and makes it soft and supple (14).

\section{Vetapalai lubricant}

It having Kushthaghna, anti-inflammatory, antibacterial, antiviral, antifungal, anti-microbial, antioxidant properties. All the contents are Vata, Pitta, Kapha Shamak, Twachya. It moisturizes and soothes the skin (15).

\section{Conclusion}

The Plaque Psoriasis can be correlated with Eka-Kushtha, which is a type of Kshudra Kushtha. From the above case it can be concluded that the EkaKushtha can be successfully treated with the Shodhan and Shaman Chikitsa.

\section{References}

1. Munjal Y.P. , API Textbook of Medicine, volume 1, 2015 ,pg. 678 .

2. Zaidi Z. and S.W.Lanigan, Dermatology in Clinical practice, Immune system of the skin, SpringerVerlag London Limited, 2010, pg. 185.

3. Shukla and Ravi Dutt Tripathi, Agnivesh, Charak samhita, Chakrapani Commentary, Indriyasthan Chapter 9, shloka 8, Varanasi:Chowkhamba Sanskrit Pratishthan 2009.

4. Shukla and Ravi Dutt Tripathi, Agnivesh, Charak samhita, Chakrapani Commentary, Nidansthan Chapter 5, shloka 4, Varanasi:Chowkhamba Sanskrit Pratishthan 2009.

5. Tripathi Bramhananda, Charak Samhita, Chapter 7/21, Chaukhamba Surbharati Publication, Varanasi, 2009

6. Tripathi Bramhananda, Ashtanga Hridaya of Vagbhatta, Sutrasthana, 17/22, Chaukhamba Sanskrit Pratishthana, Delhi, 2015, p. 216.

7. Vaghbhatacharya, ashtanghridaya, sutrasthan, snehav idhiadhaya. $13 / 45$ edi $t$ e d by Dr. Annamoreshvara kunnte,, edition. Reprint 2010 chaukamba sansthana Varanasi, p, 249.

8. Shukla and Ravi Dutt Tripathi Agnivesha, Charak Samhita, Chakrapani Commentary, Chikitsasthan chapter 21, shloka 15, editors, Varanasi: Chowkhamba Sanskrit Pratishthan; 2013.

9. Bramhashankar Mishra, Bhaishajya Ratnavali, Vol III edition 1st, 54/257- 260, New Delhi: Chaukhamba Sanskrit Bhavan; 2006. p.82

10. Sharma HM. Butter oil (ghee) - Myths and facts. Indian J Clin Pract. 1990;1:31-2

11. Bramhashankar Mishra, Bhaishajya Ratnavali,VolIII edition 1st, 54/301- 302, New Delhi: Chaukhamba Sanskrit Bhavan; 2006, p. 92

12. Trikamji VJ , Susruta samhita, Chikitsa Sthana, Chapter 33, shloka 10, Varanasi, India: Chowkhamba Krishnadas Academy; add, p. 163.

13. SaokarR,et al, Screening of Antibacterial and Antifungal Activity of Gandhaka Rasayana- an Ayurvedic Formulation, International Journal of Recent Trends in Science And Technology, ISSN2277-2812 E-ISSN 2249-8109, Volume 8, Issue 2, 2013 ,pp 134-137.

14. https://www.ayurvedaforall.com/atrisormoisturizer.html date 03-01-2020 time 15.45.

15. https://www.amazon.ae/Dr-stanles-PsoreaseEffective-Psoriasis-treatment/dp/B07B3T2c95 date 03-01-2020 time 14.00. 